\title{
Study on Consumer Perception and Purchase Behavior of Computer in Salem District, Tamil Nadu
}

\author{
A. Chitra ${ }^{1}$ and R. Gopinath ${ }^{2}$ \\ ${ }^{1}$ Associate Professor, Sri Ganesh School of Business Management, Salem, Tamil Nadu, India \\ ${ }^{2}$ D. Litt. (Business Administration), Researcher, Madurai Kamaraj University, Madurai, Tamil Nadu, India \\ E-mail: ananthnarayanchitra@gmail.com,dr.raju.gopinath@gmail.com
}

\begin{abstract}
Computer is the integral part of every individual's life in present era. That too in present scenario everybody needs their computer to carries over their daily operations. This increased need of computers need the customer's opinion and factors influencing the decision on computer purchase. This paper elucidates the consumer's behavior and perception during computer purchase in Salem district. The study has conducted with the objective of analyzing the perception of consumer during computer purchase and the factors influencing the computer purchase, and to suggest the factors to be considered while marketing the computers. The list of computer users is obtained from various sources and $\mathbf{3 0 0}$ samples were selected for this study based on stratified random sampling technique with equal weight age to each statra. The data was collected by send structured questionnaire to the customer's email address which is collected from various selling outlets. The collected data were analyzed using descriptive analysis and chi squire analysis. Analysis explains certain demographic factors have influence on the perception on computers and family and other close circle, monthly income, occupation are also has role in determining the purchase. Even though we have tailor made computers, branded one is the choice of the customer that too the customers prefer buying in stores rather than online purchase.
\end{abstract}

Keywords: Consumer Perception, Purchase Behavior, Computer

\section{INTRODUCTION}

\section{A. Consumer Buying Behavior}

In this modern world we people give much importance for Electrical and Electronic devices, without that we cannot make our life easier in this busy world. And these electronic devices are essential to cater the sophisticated, easy life style of the individuals. Man wants to have information on his table whenever and whatever he wants. The need for information has grown in the fast developing environment. The thirst for information has paved way for innovating various machines for his modern living. Computer is one such machine invented by him. Now computers are highly helpful to rule a nation itself. The importance of computers increases day by day in multi-directions. The time and cost saving aspects have induced the common man also to use computers. Today's situation makes it as more essential to all from the students to general managers need their own computer, to perform their daily routines. Students are attending online classes; most of the other professions reporting their work through computer and this machine is an intensive and integral component of today's era. The physical strain is also relieved to a maximum extent by using computers. Hence many consumers prefer to buy computers for their day to day operations. As the computers are durables, expensive and prestigious, consumers consider several factors during the purchase of computers.

Richard Bushkisk (1970) in his book on "Principles of Marketing" says that the present day consumer is said to have the sovereignty in the market and the success of marketing depends upon the ability of the marketer to satisfy the consumer. In fact marketing starts with the consumers and ends with the consumers. "The consumer is the engine of economic activity and his prerogatives are no less than those of the monarch. He is the fulcrum or the pivot upon which the business moves. However the consumers differ in their tastes, economic position and social status. The buying situations, purchases decisions, purchase feelings, need arousal, evaluation of consumer behavior and the like also assume special significance. To understand the mindset of consumers it is essential to know the perception and the behavior of the consumer. Consumer behavior is the study on the behavior of consumers in the process of deciding whether to purchase or not, or whether to use or not, whether to dispose of or not to dispose of the products which is required to satisfy their needs. The term 'consumer behavior' refers to the behavior of both the personal consumer and the organizational consumer. There are enormous factors which influenced this consumer behavior and this is the determinant of purchasing decision. The common behavior influencers are brought-up culture, referral group; age and life cycle of the individual buyer, perception towards the product are the prominent influencers. This study is conducted to analyze and find the factors influencing the consumer perception and purchasing behavior of individuals while purchasing the computers.

\section{B. Types of Consumer Behaviour}

A consumer's purchasing decisions is determined by on the type of products that they need to buy. The behaviour of a consumer while buying consumables has a lot different while buying durables. Based on the observations, it is clear that arriving to purchase decision is more complex, expensive, involved many more participants. Consumer 
buying behaviour is determined by the level of involvement that a consumer shows towards a purchase decision.

There are four type of consumer buying behaviour: [1] Complex buying behaviour, [2] Dissonance-reducing buying behaviour, [3] Habitual buying behaviour and [4] Variety seeking behaviour.

\section{Complex Buying Behaviour}

Complex buying behaviour is met particularly when consumers are buying an expensive and durable product. In this infrequent transaction, consumers are highly involved in the purchase decision. Consumers will do a vast research thoroughly before committing to purchase. Consumer behaves very different when buying an expensive product or a product that is unfamiliar to him. When the risk of buying a product is very high, a consumer consults friends, family and experts before making the decision.In complex buying behaviour, the buyer will pass through a learning process. He will first develop beliefs about the product, then attitudes, and then making a thoughtful purchase choice. For complex buying behaviour customers, marketers are expected have a deep understanding of the products.

\section{Dissonance-Reducing Buying Behaviour}

In dissonance-reducing buying behaviour consumer involvement in purchase is very high but they don't do much research since they are having with few choice. This might be due to high price and infrequent purchase. For certain products there is a low availability of product choices and there are no significance differences among brands. In this type, a consumer buys a product which is easily available to him/her. Consumers will be forced to buy goods that do not have too many choices and therefore consumers will be left with limited decision making. Based on the products available, time limitation or the budget limitation, consumers buy certain products without a lot of research. Marketers of these kinds of products may run after-sale service camps to remind their brand in the minds of consumers. These campaigns should aim to support consumers and convince them to continue with their choice of their brand. These marketing campaigns should focus on building repeat purchases and referrals by offering discounts and incentives.

\section{Habitual Buying Behaviour}

Habitual Buying Behaviour is represented that the consumer has low involvement in a purchase decision, and they use to make the decisions by practice. In this case the consumer couldn't find much difference between brands. When buying products that they use for their daily routine, they do not do much research before buying these kinds of products. They either go by their favourite brand or the one that they are using regularly or the one available in the store or the one that costs the least. For these kinds of products there will not be any brand loyalty from customers.
Most of the times habitual buying behaviour is influenced by radio, television and print media. Besides, consumers are buying based on brand familiarity. Therefore marketers must use repetitive advertisements to build brand familiarity.

\section{Variety Seeking Buying Behaviour}

In case of variety seeking consumer behaviour, consumer participation is low. Even though there are significant differences between brands, consumers often do a lot of brand switching because of the vast availability of brands consumers might want to try out new products just out of curiosity or boredom. Consumers here, generally buy different products not because of dissatisfaction but mainly with an urge to seek variety. Marketers have to adopt different strategies to retain the customer of such type of behaviour. Marketers avoid out-of-stock conditions, sponsor frequent advertising, offer lower prices, discounts, deals, coupons and free samples to attract consumers.

These are the type regular consumer behaviour, but it need not be the same for all type of the products. In case of the durable products like computer the behaviour pattern is different.

\section{Consumer Behavior Specifically while Buying Computers}

It is seen that usage of computer is increasing day by day. The usage of computer technology has increased and it is essential over time in every sector. Moreover, with the amazing capacity of storage, transferring and accessing the information whenever it is required and anywhere has increased use of the computers. It is witnessed that emergence of technology and time has made prices of the computers more affordable. The inbuilt speakers, storage, enabled internet connectivity and adequate battery made the computers not necessary to purchase and plug in additional accessories; hence the overall cost and the space required to the consumer is perceived to be lesser. Consideration with above all factors alone with brand power determines the buying behavior of computers.

\section{REVIEW OF LITERATURE}

Customer is the boss for any business; it is indispensable to understand the psychology behind the purchasing decision of a consumer for securing the competitive edge. The ultimate purpose of any business is to create and retain the customers. The success of a business relies not on what the business man is ready to produce, rather it relies on producing what the customer is ready to purchase. Consumer use to make an intensive research before purchasing durables, they do lot of reviews and use almost all the sources of their references before making their purchase decision (Bindu Raj, 2001; Gopinath and Kalpana, 2019). There are enumerate reasons behind a purchase decision, range from price affordability, brand preference, reference influence, convenience and availability in nearby 
areas, after sale service are few of them. Debashis Pati (2002) and Mokrysz (2016) consider brand has the predominant position in purchase decision. According to the author consumers are human beings so they analyze on brands, express about brands, think about brands, feel about brands, compare brands, choose brands, and even recommend brands to others. As the band is playing a prominent role in purchasing decision, the company is taking too much care to develop and maintain the brand image. The brand is created in such a way that it explains about the product and easily remember able to the customers (Gopinath, 2019b).

Corporate governance is the set of rules, guidelines and processes that guide and control the company. Corporate governance primarily involved in satisfying the interests of many stakeholders, such as shareholders, management, employees, customers, suppliers, financiers, governments and general public. As corporate governance also provides guidelines for achieving corporate objectives, it effectively covers all areas of management, start from business plans and internal controls to performance appraisal and corporate disclosure. The study of Bechrer (2004) and Rabia Jahani Farzana et al. (2010) find that the consumer who worried about the proximity and availability of shops would mostly prefer online purchasing rather than personal visit to the shops. According to Monira Begum et at. (2020) the purchasing decision and the buying behavior are dominated by the price and the product range of the particular product. There is wide range of reference sources like friends, relatives, advertisements etc. (Gopinath and Kalpana, 2011a), among these things advertisement has an important role in decision making process, that too television and online advertisements has a considerable influence than the other Medias (Maruthamuthu et al., 2006; Ahasanul et al., 2007).

In some cases family members are also major influencers, especially kids are the prominent influencers (Chitra, 2020). When it is a non-durable, price of the product and the discounts available holds the first position in purchasing decision (Gopinath and Kalpana, 2011b), but it is not same for the case of durables (Kimes and Sheryl, 2002). The perceived risk and perceived benefit from the product and the seller is also an influencer in purchasing decision. Even though the consumers prefer online buying due to various reasons still some of them are convenient and trust with hand in hand and personal interaction with the sellers (Kim et al., 2009; Gopinath, 2019 e). Since the computer is a durable one the after sales service is also matters in computer purchase, the reliability and the availability of service units and the spare parts are also a determinant in the purchasing decision (Parthasarathy, 1993).

When rest of things is satisfied consumers also do bother about the speed, storage capacity, and other add on facilities available in the computers. Even though there are vast number of factors to influence the consumer perception on a product and purchase behavior of an individual, the perceived satisfaction from the product place a predominant role, and his opinion about the product is positive only when the product features met the perceived satisfaction level of the consumer.

\section{OBJECTIVES OF THE STUDY}

1. To explore the relationship between of demographic variables like Gender, Age, Monthly Income, Occupational status and the various factors influencing the purchasing decision.

2. To study the factors influencing the purchase decision of computers.

3. To study the factors influencing the customers' satisfaction.

\section{MATERIALS AND METHOD}

\section{A. Sampling}

The sample unit is the individual customers. They are scattered and they are not easily identifiable due to the vast area selected for the purpose of the study. Hence the sellers are contacted in person to get the address of the consumers. Further, computer service centers, friends and relatives are also contacted for the purpose of getting the residential addresses of the consumers. A list of persons possessing computers, as per the details provided by the sellers, computer service centers, friend and relatives are prepared. Out of the list a sample of 300 computer owners are selected on the basis of stratified convenient sampling method. The stratification is based on socio economic status of the geographical location. So the cluster of urban, semi urban and rural places is considered as one statra. By giving equal priority to each statra, 100 samples from the cluster of urban areas, 100 samples form the cluster of semi urban areas and another 100 samples from the cluster of rural areas were collected for the purpose of the study.

\section{B. Data Collection Procedure}

The present study includes both primary and secondary source of data. After completing the address collection from various sources, that has been segmented based on the geographical location of the respondent. After that structured questionnaire was sent to the e mail address of the respondent and they were requested to exhibit their opinion. Extensive secondary data from journals and websites is also used in this study.

\section{Ethical Consideration}

After collecting the data form the various sales sources, the respondents were randomly selected based on their dwelling location. The selected respondent has been requested informed through phone call regarding the survey. After getting the consent of the respondent the structured preadministered questionnaire was sent to their e-mail address. All the respondents were made to know that they are free to back out of the study at any point in time and that 
information obtained from them as well as their identities will be kept anonyms and strictly confidential.

\section{ANALYSIS}

A. Relationship between Demographic Variables and the Various Factors Influencing the Purchasing Decision

\section{Association between Gender and Brand preference of the Computer}

Gender of the respondent has a significant influence in the selection of a particular brand of computer. In order to analyze the relationship between the gender and the brand of computer possessed by the respondents, the null hypothesis is framed as follows.

$H_{0} 1$ : There is no significant association between the gender and the brand preference of computer.

It is noted from the table I the P value is greater than 0.05 for the relationship between brand preference and gender is significant at $5 \%$. Hence the null hypothesis stating there is no significant relationship between gender and the brand preference is accepted. So it can be sated that the brand of computer possessed by the respondents is not having significant association with the gender of the respondents.

TABLE I ASSOCIATION BETWEEN GENDER AND BRAND PREFERENCE OF THE COMPUTER

\begin{tabular}{|c|c|c|c|c|c|c|c|c|}
\hline \multirow{2}{*}{ Gender } & \multicolumn{6}{|c|}{ Brand } & \multirow{2}{*}{$\begin{array}{c}\text { Chi } \\
\text { Square value }\end{array}$} & \multirow{2}{*}{ P Value } \\
\hline & DELL & HCL & HP & LENOVA & Assembled & Total & & \\
\hline Male & 38 & 43 & 44 & 40 & 15 & 180 & \multirow{3}{*}{5.27} & \multirow{3}{*}{1.234} \\
\hline Female & 20 & 22 & 31 & 32 & 10 & 120 & & \\
\hline Total & 58 & 65 & 75 & 72 & 25 & 300 & & \\
\hline
\end{tabular}

2. Association between Age of the respondent and Purpose of Possession of Computer

Age is an important factor in determining the purpose for which the computer is used. The usage is ranging from playing games, education, business, office work.
In the present study analyze the relationship between age and the purpose of possession of computer. For the above stated purpose the null hypothesis is framed as follows:

$H_{0}$ 2: There is no significant association between the age of the respondent and the purpose of possessing the computer.

TABLE II ASSOCIATION BETWEEN AGE OF THE RESPONDENT AND PURPOSE OFPOSSESSION OF COMPUTER

\begin{tabular}{|c|c|c|c|c|c|c|c|}
\hline \multirow{2}{*}{$\begin{array}{c}\text { Purpose } \\
\text { of Possession }\end{array}$} & \multicolumn{4}{|c|}{ Age Group (Years) } & \multirow[b]{2}{*}{ Total } & \multirow{2}{*}{$\begin{array}{c}\text { Chi } \\
\text { Square value }\end{array}$} & \multirow[b]{2}{*}{ P-Value } \\
\hline & Below 20 & 21-30 & $31-40$ & $\begin{array}{c}\text { Above } \\
40\end{array}$ & & & \\
\hline $\begin{array}{l}\text { Education and } \\
\text { Entertainment }\end{array}$ & 36 & 20 & 21 & 3 & 80 & \multirow{4}{*}{11.23} & \multirow{4}{*}{0.000} \\
\hline Office Use & 8 & 43 & 30 & 15 & 96 & & \\
\hline Business Use & 3 & 41 & 45 & 35 & 124 & & \\
\hline Total & 47 & 104 & 96 & 53 & 300 & & \\
\hline
\end{tabular}

Table II states the $\mathrm{P}$ value 0.00 which is less than 0.01 , hence the null hypothesis stating there is no significant association between age of the respondent and purpose of possessing the computer holds no good. It can be concluded that the age of the respondent has significance in purpose of holding the computer. Blow 20 years age group majorly using computer for the purpose of entertainment, 21-30 years, 31-40 years and above 40 years age group are using for the purpose of office and business. So the age of the respondent has influence with the purpose of using the computers.

3. Association between Monthly Income of the Respondent and the Mode of Arranging Finance for Purchasing Computer
Income of the respondent is the one factor which determines his purchasing power. For the purpose of this study the monthly income has classified as up to 20000, 20001 to 30000, and 30001 to 40000 and above 40000. The null hypothesis as follows:

$H_{0} 3$ : There is no significant association between the monthly income of the respondent and the mode of arranging finance for purchasing the computer.

In the Table III the $\mathrm{P}$ value is less than 0.01 so the null hypothesis stating there is no significant association between monthly income of the respondent and the mode of arranging finance for purchasing the computer is rejected at $1 \%$ level of significance. 
TABLE III ASSOCIATION BETWEEN MONTHLY INCOME OF THE RESPONDENT AND THE MODE OF ARRANGING FINANCE FOR PURCHASING COMPUTER

\begin{tabular}{|c|c|c|c|c|c|c|c|}
\hline \multirow{2}{*}{$\begin{array}{l}\text { Mode of Arranging } \\
\text { finance for purchase }\end{array}$} & \multicolumn{4}{|c|}{ Monthly Income (Rupees) } & \multirow[b]{2}{*}{ Total } & \multirow{2}{*}{$\begin{array}{c}\text { Chi } \\
\text { Square } \\
\text { value }\end{array}$} & \multirow[b]{2}{*}{ P Value } \\
\hline & $\begin{array}{c}\text { Up to } \\
20,000\end{array}$ & $20,001-30,000$ & $30,001-40,000$ & 40,000 & & & \\
\hline Cash & 12 & 31 & 42 & 40 & 125 & \multirow{4}{*}{13.45} & \multirow{4}{*}{0.000} \\
\hline Bank Finance & 44 & 22 & 19 & 12 & 97 & & \\
\hline Private Finance & 41 & 15 & 12 & 10 & 78 & & \\
\hline Total & 97 & 68 & 73 & 62 & 300 & & \\
\hline
\end{tabular}

The respondent having less than 20000 of monthly income prefers to purchase by bank finance and private finance. And the respondents having monthly 20001-30000, 3000140000 and above 40000 incomes prefer to buy on cash instead of going to private and bank finance.

4. Association between Occupational Status of the Respondent and the Mode of Purchase

The occupational status of the respondent is the one factor which is expected to have influence on the mode of purchasing the computer.
For the purpose of the study the occupational status of the respondents has been classified as private employees, Government employees and Business and the mode of purchase used in this study is online and off line mode. The null hypothesis is assumed as follows:

$H_{0} 4$ : There is no significant association between the occupational status of the respondent and the mode of purchasing the computer.

TABLE IV ASSOCIATION BETWEEN OCCUPATIONAL STATUS OF THE RESPONDENT AND THE MODE OF PURCHASE

\begin{tabular}{|c|c|c|c|c|c|c|}
\hline \multirow[b]{2}{*}{ Mode of Purchase } & \multicolumn{3}{|c|}{ Occupational Status } & \multirow[b]{2}{*}{ Total } & \multirow[b]{2}{*}{ Chi Square value } & \multirow[b]{2}{*}{ P Value } \\
\hline & $\begin{array}{c}\text { Private } \\
\text { Employee }\end{array}$ & $\begin{array}{c}\text { Government } \\
\text { Employee }\end{array}$ & Business & & & \\
\hline Online Purchase & 64 & 52 & 45 & 125 & \multirow{3}{*}{16.45} & \multirow{3}{*}{2.34} \\
\hline Off line Purchase & 54 & 55 & 43 & 97 & & \\
\hline Total & 105 & 107 & 88 & 300 & & \\
\hline
\end{tabular}

The Table IV has $\mathrm{P}$ value of 2.34 which is higher than 0.01 , hence the null hypothesis assuming no relationship between Occupational Status of the Respondent and the Mode of Purchase holds good and it is accepted. So it can be concluded that the occupation has no influence on the decision of mode of purchasing the computer. Whether to purchase by online mode or through one to one purchase is not decided or influenced by the occupational status of the respondent. In early days people won't have trust on online purchasing, but now we can see people are giving more preference to online purchase due to various reasons like convenience and wide range of choice. Government has taken steps to make the online purchase as trust worthy (Gopinath, 2019 a).

\section{B. Sources Influencing the Purchase Decision}

\section{Source of Information Influencing the Purchase Decision}

Consumer Behavior is exposed to many external and internal stimuli which help in decision making. It is very important to know the sources through which the consumers come to know about the computers. The data collected from the sample respondents with reference to the source of information are classified and shown as follows.

TABLE V SOURCE OF INFORMATION INFLUENCING THE PURCHASE DECISION

\begin{tabular}{|c|c|c|c|}
\hline Sl. No. & Sources & $\begin{array}{c}\text { Number of } \\
\text { Respondents }\end{array}$ & $\begin{array}{c}\text { Percentage } \\
{[\%]}\end{array}$ \\
\hline 1. & Advertisement & 74 & 25 \\
\hline 2. & Friends & 105 & 35 \\
\hline 3. & Relatives & 107 & 35.6 \\
\hline 4. & $\begin{array}{l}\text { Dealer's } \\
\text { Representative }\end{array}$ & 14 & 4.4 \\
\hline \multicolumn{2}{|r|}{ Total } & 300 & 100 \\
\hline
\end{tabular}

Table V explains the distribution of source of information influencing the purchase decision. Most of time the decision is influenced by the friends (35 \%) and Relatives (35.6\%) and a considerable portion of purchase decision are influenced by Advertisement (74 \%) and only few are considering the suggestions of dealers (4.4\%). 


\section{Persons Influencing/Involved in the Purchase Decision}

In certain cases the purchaser and the user of the computer may not be the same person. So there are few more persons involved and influencing the purchase decision rather than the buyer. For the purpose of this study Spouse, Children, Parents, Friends and Peer group, Seller are considered involving and influencing the purchase decision of the buyer.

\section{TABLE VI PERSONS INFLUENCING/INVOLVED IN THE PURCHASE DECISION}

\begin{tabular}{|c|c|c|c|}
\hline Sl. No. & Person & $\begin{array}{c}\text { Number of } \\
\text { Respondents }\end{array}$ & Percentage \\
\hline 1. & Self & 135 & 45 \\
\hline 2. & Spouse & 47 & 15.7 \\
\hline 3. & Children & 30 & 10 \\
\hline 4. & Parents & 26 & 8.7 \\
\hline 5. & $\begin{array}{l}\text { Friends and Peer } \\
\text { Group }\end{array}$ & 56 & 18.6 \\
\hline \multirow[t]{2}{*}{6.} & $\begin{array}{l}\text { Persuasion by } \\
\text { the Seller }\end{array}$ & 6 & 2.0 \\
\hline & Total & 300 & 100.00 \\
\hline
\end{tabular}

Table VI Explains the distribution of persons involved and influencing the purchase decision of computers. In majority cases the person who purchases the uses the computer might be the purchasing decision maker. In 15.7 percentage cases the spouse of the purchaser has considerable influence on the purchasing decision. 10 percentage and 8.7 percentage cases the children and parent of the purchaser influencing the decision of the purchaser. In 18.7 percentage cases the friends and peers are intruding the decision of the purchaser.
From this analysis it is clear that prominent portion of the purchasing decision is self-reliant.

\section{Factors Influencing the Level of Satisfaction of Computers}

It is a well perceived fact that customer's satisfaction has become the important factor of business success. The computer industry makes a transition from a seller oriented industry to a marketing oriented industry. In the new scenario there are companies that cater to the needs of individual customer and they are need to make tailor made products. The raising of customer service standards from customer satisfaction to customer delight will be the objective of the more proactive companies. In the transition from a seller's market to a buyer's market, the consumer will be the eventual winner. Hence an attempt is made to identify the factors influencing the customer's satisfaction.

\section{Occupational Status of the Respondent and the Level of Satisfaction}

The requirements and satisfaction of the computer primarily depends on the purpose for what it is used. The occupational status is the one which determines the usage and the extent of usage. For the purpose of this study the occupational status has been classified as private employees, government employees and business. For studying the association the null hypothesis is framed as follows.

$H_{0}$ 5: There is no significant relationship between the occupational status of the respondent and the level of satisfaction of computers.

TABLE VII ASSOCIATION BETWEEN OCCUPATIONAL STATUS OF THE RESPONDENT AND THE LEVEL OF SATISFACTION

\begin{tabular}{|c|c|c|c|c|c|c|}
\hline \multirow{2}{*}{ Occupational Status } & \multicolumn{3}{|c|}{ Level of Satisfaction } & \multirow{2}{*}{ Total } & \multirow{2}{*}{$\begin{array}{c}\text { Chi Square } \\
\text { value }\end{array}$} & \multirow{2}{*}{ P Value } \\
\hline & Highly Satisfied & Satisfied & Neutral & & & \\
\hline Private Employee & 35 & 42 & 35 & 125 & \multirow{4}{*}{17.43} & \multirow{4}{*}{2.65} \\
\hline Government Employee & 39 & 40 & 43 & 97 & & \\
\hline Business & 30 & 21 & 15 & 66 & & \\
\hline Total & 104 & 103 & 93 & 300 & & \\
\hline
\end{tabular}

Table VII explains the relationship between occupational status of the employee and the level of satisfaction on computers. Since the $\mathrm{P}$ value is greater than 0.01 the null hypothesis stating there is no significant association between the occupational status and the level of satisfaction is accepted. It can be concluded that the satisfaction level on computer is not determined by the occupation category of the respondent.

\section{Type of Computer and Level of Satisfaction}

The computers may be of two kinds one is assembled computer and another one is branded one. And the features vary accordingly. So the level of satisfactions of the respondent may be influenced by the type of computer. For the purpose of analysis the null hypothesis is framed as follows:

$H_{0} 6$ : There is no significant relationship between the type of computer of the respondent and the level of satisfaction of computers.

Table VIII has the $\mathrm{P}$ value less than 0.01 at $1 \%$ level of significance, hence the null hypothesis assuming no relationship between type of computer and the level of satisfaction holds no good and it is rejected. 
TABLE VIII ASSOCIATION BETWEEN TYPES OF COMPUTER OF THE RESPONDENT AND THE LEVEL OF SATISFACTION

\begin{tabular}{|c|c|c|c|c|c|c|c|}
\hline \multirow[b]{2}{*}{ Type of computer } & \multicolumn{4}{|c|}{ Level of Satisfaction } & \multirow[b]{2}{*}{ Total } & \multirow{2}{*}{$\begin{array}{c}\text { Chi Square } \\
\text { value }\end{array}$} & \multirow{2}{*}{$\begin{array}{c}\mathbf{P} \\
\text { Value }\end{array}$} \\
\hline & $\begin{array}{c}\text { Highly } \\
\text { Satisfied }\end{array}$ & Satisfied & Neutral & Dissatisfied & & & \\
\hline Branded & 65 & 43 & 35 & 12 & 155 & \multirow{3}{*}{4.43} & \multirow{3}{*}{0.00} \\
\hline Assembled & 40 & 30 & 42 & 33 & 145 & & \\
\hline Total & 105 & 73 & 77 & 45 & 300 & & \\
\hline
\end{tabular}

The above analysis explains the relationship between the type of computer and the level of satisfaction and according to the analysis branded computers are the choices of customer where the satisfaction level is high and the dis satisfaction level is low. Where as in case of assembled computers the levels of satisfaction is comparatively low and dis satisfaction level is comparatively high. The reasons for customer's preference on branded computers instead of assembled one is, the branded computer makers has the social responsibility to produce good and quality products (Gopinath, 2019c) than of assembled computer makers.

\section{Brand of Computer of the Respondent and the Level of Satisfaction}

Brand is an important factor associated with the level of satisfaction, for the purpose of this study DELL, HCL,HP, LENOVA, and Assembled system are the brands considered based on the sales opinion of the sellers.
And this study attempted to explain the relationship between brand of the computer and the level of satisfaction. The null Hypothesis framed as follows:

$H_{0} 7$ : There is no significant relationship between the Brand of computer of the respondent and the level of satisfaction of computers.

The Table IX has P value less than 0.05; hence the null hypothesis stating that there is no significant relationship between the brand of computers and the level of satisfaction holds no good and it is rejected at 5\% level of significance. It can be concluded that there a significant relationship between the brand and the level of satisfaction and the brand has power to decide the satisfaction level of computers. People using DELL, HCL, HP, LENOVA which are the brands considered for this study are more satisfied compared to the users using assembled computers.

TABLE IX ASSOCIATION BETWEEN BRAND OF COMPUTER OF THE RESPONDENT AND THE LEVEL OF SATISFACTION

\begin{tabular}{|c|c|c|c|c|c|c|c|}
\hline \multirow[b]{2}{*}{ Brand of Computer } & \multicolumn{4}{|c|}{ Level of Satisfaction } & \multirow[b]{2}{*}{ Total } & \multirow{2}{*}{$\begin{array}{c}\text { Chi Square } \\
\text { value }\end{array}$} & \multirow[b]{2}{*}{ P Value } \\
\hline & $\begin{array}{c}\text { Highly } \\
\text { Satisfied }\end{array}$ & Satisfied & Neutral & Dissatisfied & & & \\
\hline DELL & 33 & 22 & 6 & 2 & 63 & \multirow{6}{*}{7.89} & \multirow{6}{*}{0.034} \\
\hline HCL & 30 & 28 & 4 & 3 & 65 & & \\
\hline HP & 40 & 28 & 7 & - & 75 & & \\
\hline LENOVA & 35 & 32 & 5 & - & 72 & & \\
\hline Assembled & 10 & 11 & - & 4 & 25 & & \\
\hline Total & 148 & 121 & 22 & 09 & 300 & & \\
\hline
\end{tabular}

\section{FINDINGS OF THE STUDY}

The findings of the research analysis have given a generalized view on the consumer perception and purchase behavior of Computer. The analysis has been divided into three parts, the first part deals with the relationship between demographic variables and the various factors influencing the purchasing decision and it is found that There is no significant association between the Gender of the respondent and their brand preference, and it can be concluded that Gender has nothing to do with choosing the brand of the computer. But when analyzing the association between age of the respondent and purpose of possessing the computer, the relationship was highly significant, the respondents below the age of 20 tend to use the computers more for the purpose of education and entertainment but the respondents ranging from 21 to 40 prefers computers mostly for the purpose of office and business use. The analysis also focuses on the association between the monthly income of the respondent and the mode of arranging fiancé for purchasing the computers. Here the respondents having income less than 20000 has least preference on cash purchase and they are interested in getting financial support either from bank or prom private finance. When analyzing about the priority of online or off line purchase of computers, the occupation of the respondent has no priority in deciding the mode of purchasing the computers. The second part of the analysis deals with the Sources 
influencing the purchase decision and the researcher find that friends and relatives of the respondent has considerable influence in purchasing decision rather than the advertisements and other sources (Gopinath, 2019d). When listing the persons who has influence on the purchasing decision of a computer, self-decision predominates, followed by the influence of spouse children, parents and friends and peer group. The influence of seller stood last. The third part of the analysis is about factors influencing the Level of Satisfaction of Computers. From the analysis it's found, there is no association between the occupation of the respondent and the level of satisfaction of the computer. But the brand of the computer has some association with the level of satisfaction of computer.

\section{CONCLUSION}

Certain demographic factors like age and monthly income of the respondents has influence on the perception and purchasing behavior of the computer but the factors like gender and occupational status of the respondent are not found to have influence on the purchasing intention. One an individual decided to purchase something; there are several sources and persons who influence the purchasing decision. For the case of computer purchase, the friends and relatives are the prominent influencers and spouse and children of the purchaser is also involved in the purchasing decision. Branded products are always has a place in the minds of customers (Gopinath and Irismargaret, 2019) this is same in the case of computers. Customers are more satisfied with branded computers than assembled one, but their satisfaction on different brands is not much varying. So it's recommended for the sellers and manufactures to concentrate in promoting branding computers and the recommended mode of selling is one to one sale, instead of online sale.

\section{REFERENCES}

[1] Ahasanul Haque., \& Ali Khatibi. (2006). The Study of the Behavior of Malaysian Consumers towards Online Shopping. Asian Journal of Information Technology, 5(1), 12-19.

[2] Bechrer, C. (2004). Characteristics and Internet Marketing Strategies of Online Auction sellers. International Journal of Internet Marketing and Advertising, 24(1), 24-37.

[3] Bindu Raj, R. (2001). A Study on Marketing of Electronic House Hold Articles in Nagapattinam Revenue Division with Special
Reference to its Consumer Behaviour, M.Phil. Dissertation Submitted to Bharathidasan University, Tiruchirappalli.

[4] Chitra, A. (2020). Impact of Socio Economic Status of Parents' on the Emotional Intelligence of Generation Alpha Kids. International Journal of Latest Technology in Engineering, Management \& Applied Science, 9(5), 46-49.

[5] Debashis Pati. (2002). Branding Concepts and Process, Macmillan India Limited.

[6] Gopinath, R. (2019a). A study on Awareness of Consumers Protection Initiatives of State Government, IMPACT: International Journal of Research in Humanities, Arts and Literature, 7(5), 60-66.

[7] Gopinath, R. (2019b). Consumer Perception on Brand Awareness of Household Fabric Care Products, International Journal of Scientific Research and Reviews, 8(2), 3418-3424.

[8] Gopinath, R. (2019c). Corporate Governance's Responsibilities in Socially, International Journal of Advance and Innovative Research, 6(2) (XXXV), 207-211.

[9] Gopinath, R. (2019d). Factors Influencing Consumer Decision Behaviour in FMCG. International Journal of Research in Social Sciences, 9(7), 249-255.

[10] Gopinath, R. (2019e). Online Shopping Consumer Behaviour of Perambalur District, International Journal of Research, 8(5), 542547.

[11] Gopinath, R., \& Irismargaret, I. (2019). Reasons for a Brand Preference of Consumer Durable Goods. Research Directions, Spl. Issue, 167-174.

[12] Gopinath, R., \& Kalpana, R. (2011b). A Study of Select Discount Store Retail for the purpose of identifying factors in regards to Shopping Motives in Tamil Nadu. Inventi Rapid: Retailing \& Consumer Services, 2(2).

[13] Gopinath, R., \& Kalpana, R. (2019). A Study on Consumer Perception towards Fast Food Retail Outlet in Perambalur District. International Journal for Research in Engineering Application \& Management, 5(1), 483-485.

[14] Kim, D. J., Ferrin D. L., \& Rao H. R. (2009).Trust and Satisfaction, Two Stepping Stories for Successful E-Commerce Relationships: A Longitudinal Exploration. Information System Research, 20(2), 237257.

[15] Kimes., Sheryl E. (2002). Perceived fairness of yield management. Cornell hotel and restaurant Administration Quarterly, 21-30.

[16] Maruthamuthu, K., Krishnakumar, K., \& Vasan, M. (2006).Consumer Behaviour and Brand Preference of Cars - An Empirical Study with Reference to Salem, Tamil Nadu, Journal of Marketing.

[17] Mokrysz, Sylwia. (2016). Consumer preferences and behavior on the coffee market in Poland. Forum Scientiae Oeconomia, 4, 91-108.

[18] Monira Begum., Md Nahid Hossain., Md Zillur Rahman., \& Md Jamal Uddin, (2020). Assessment of consumer perception and purchase behavior of laptop in Bangladesh. Discovery, 56(299), 735747

[19] Parthasarathy, B. N. V. (1993). Customer Service the Real Issues, The Financial Express, 7.

[20] RabiaJahani Farzana, G., Arun Kumar, K., \& Gopinath, R. (2010). The Study on Determinants of Retail Shopper's Perception and Experience in Pantaloons Big Bazaar in Chennai. Marketing Management, Macmillan Publishers India Ltd., 439-446.

[21] Richard Bushkisk. (1970). Principles of Marketing. Illinois's: The Dryden Press. 